\title{
Decision Support System Based on Benefit Cost Ratio Method for Project Tender
}

\author{
Siti Hardiyanti Rukmana*1, Much Aziz Muslim ${ }^{2}$ \\ Department of Computer Science, Semarang State University, Indonesia \\ *Corresponding author, e-mail: sitihardiyantirukmana2@gmail.com
}

\begin{abstract}
The procurement process became one of the important aspects for PT. PLN (Persero) to operate the company. One way to meet these needs is through the project tender. The tender process aims to get high-grade materials with the lowest prices that meet the criteria of efficiency PT. PLN (Persero). In order to simplify the bidding process required a decision support system. The method used in this system is Benefit Cost Ratio (BCR). Input in this application are the documents and the tender offer price from bidders with complete tender documents that have been validated by prospective bidders and then selected by the tender committee to make an assessment and validation winner. The output of this process is the winner of the tender project based on calculations Benefit Cost Ratio (BCR). Therefore, the method Benefit Cost Ratio (BCR) can be used as a decision support system to determine the winner of the project tender.
\end{abstract}

Keywords: decision support systems, project tender, benefit cost ratio

Copyright $@ 2017$ APTIKOM - All rights reserved.

\section{Introduction}

PT. PLN (Persero) is one of the State Owned Enterprises (SOEs) were commissioned to carry out the electricity supply business. APP Semarang is one implementation unit in the PT. PLN (Persero) P3B Java, Bali which is responsible for managing the operation and maintenance of power installations from Semarang up to Cepu. The procurement process became one of the important aspects for PT. PLN (Persero) to carry out the company. The materials required by PLN in this case such as diesel engines for power generation, the engine radiator, electrical wiring, and so on. One way to meet the needs of these materials is through the project tender. Tender project aims to obtain high-grade materials with the lowest prices that meet the criteria of efficiency PT. PLN (Persero). The evaluation process which is conducted in the conventional tender will cause existence of tender conspiracy where businessmen cooperating with other businesses to dominate the market by regulating and determining the winning bidder so that it can lead to unfair competition. Therefore, we need a decision support system to minimize the occurrence of bid rigging in determining the winning bidder. It can be used as a "second opinion" or "information sources" that can be used as consideration for PT. PLN (Persero) APP Semarang to determine the winner of the project tender.

\section{Literature Review}

The system is a group of elements that are integrated with a common purpose to achieve the objectives [1].

\subsection{Decision Support System}

Decision support system is an interactive information system that provides information, modeling and manipulation of data [2]. The system was used to aid decision-making in situations semistructured and unstructured situations, where no one knows exactly how the decision should be made. 


\subsection{Benefit Cost Ratio Method}

Benefit Cost Ratio (BCR) is the method used to determine the amount of gains / losses and the feasibility of a project. BCR method gives emphasis to the value of the aspect ratio of benefits to be gained by aspects of costs and losses that will be covered [3].

\subsection{PHP}

PHP is a server-side language-scripting that integrates with HTML to create dynamic web pages [4].

\subsection{MySQL}

MySQL is one type of database server that is very well known and widely used to build web applications that use the database as a source and processing of data [4]. MySQL is a database which is client server, where the data is placed on a server that can be accessed through a client [5].

\section{Research Methods}

The research method in this system is a method of Software Development Life Cycle (SDLC) with the Waterfall model. The waterfall model is a classic model that is systematic, sequential in building software [6]. Waterfall is a software development methodology that proposes a systematic approach to software and sequential start at the level of progress in the whole system analysis, design, code, test and maintenance. The stages of the waterfall method are:

a. Requirements Analysis

At this stage, an analysis of requirements the project tender PT. PLN (Persero) APP Semarang.

b. Design

At this stage, the design of the display system, such as layout design (layout), create a favicon, makes slide images, create menus, and so on.

c. Coding

At this stage, the conversion of the system design into a programming language to get the appropriate system interface and program code to make a decision support system based on the calculation of Benefit Cost Ratio.

d. Testing program

At this stage the system test whether the project bidding decision support system has been running well or an error condition exists. If they found error, then the evaluation and improvement of the system.

e. Implementation and maintenance program

This stage is the last stage in the waterfall model. Project bidding decision support system that is so executed and performed maintenance. Maintenance included in correcting errors that are not found in the previous step.

\section{Result and Discussion}

\subsection{Database System}

The decision support system is created using PHP and MySQL. The database system consists of 11 Tables of administration, news, evaluation, pricing, qualification, packages, winners, companies, participants, technical, and user. Database system is shown in Figure 1.

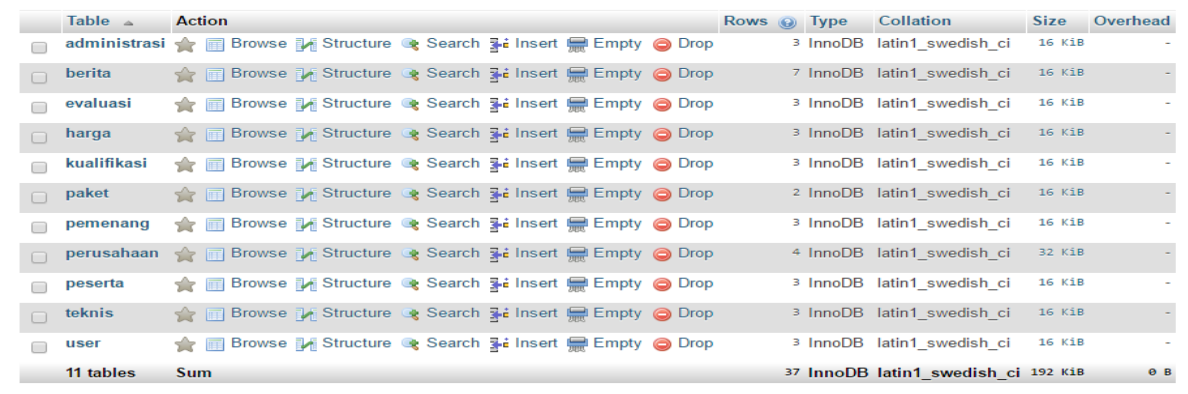

Figure 1. Database system 


\subsection{Authentication and Authorization System}

Authentication is the process in order to validate the user at the time of entering the system. Authentication in this system is the form of the login process. This system has three levels, namely the admin user, the committee and the company. The committee can only be added by the admin while companies that do not already have an account can register as bidders prior to login. Display the login page shown in Figure 2.

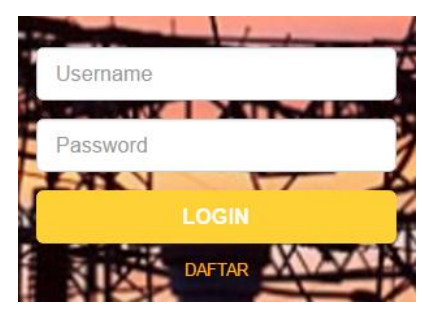

Figure 2. Login page

After the user logs into the system to input a username and password, then the system will check the suitability of the username and password. If the username and password do not match, then the notification will appear username or password is incorrect. Conversely, if the username and password match, then the next process is the authorization process. Authorization is the process of granting rights access to the user menu. This authorization is set up by the admin as the holder of the highest privileges. Users who successfully log in can access the menu in accordance with the rights access. The authorization system is necessary so that the user does not have authority over cannot access the system as a whole / Full Access System.

\subsection{Input Tender Document}

After the authentication and authorization process goes well, the next process is to make the input of tender documents. In this system, companies that registered as bidders must complete the tender documents consisting of qualifications, administrative, technical, and price. In this system, each of the qualifying criteria, administrative, and technical has five sub-criteria. While the pricing criteria have only one sub-criteria. In addition, bidders also have to input a price quote. Basically the company organizing the tender has given Self-Estimated Price (HPS), which has been informed in the tender package. Bidders who have bid lower prices of Self-Estimated Price (HPS) will provide more value for the participants of the tender. Format tender documents is entered pdf except that input prices on offer, there are a number format in the rupiah. Input tender document shown in Figure 3.

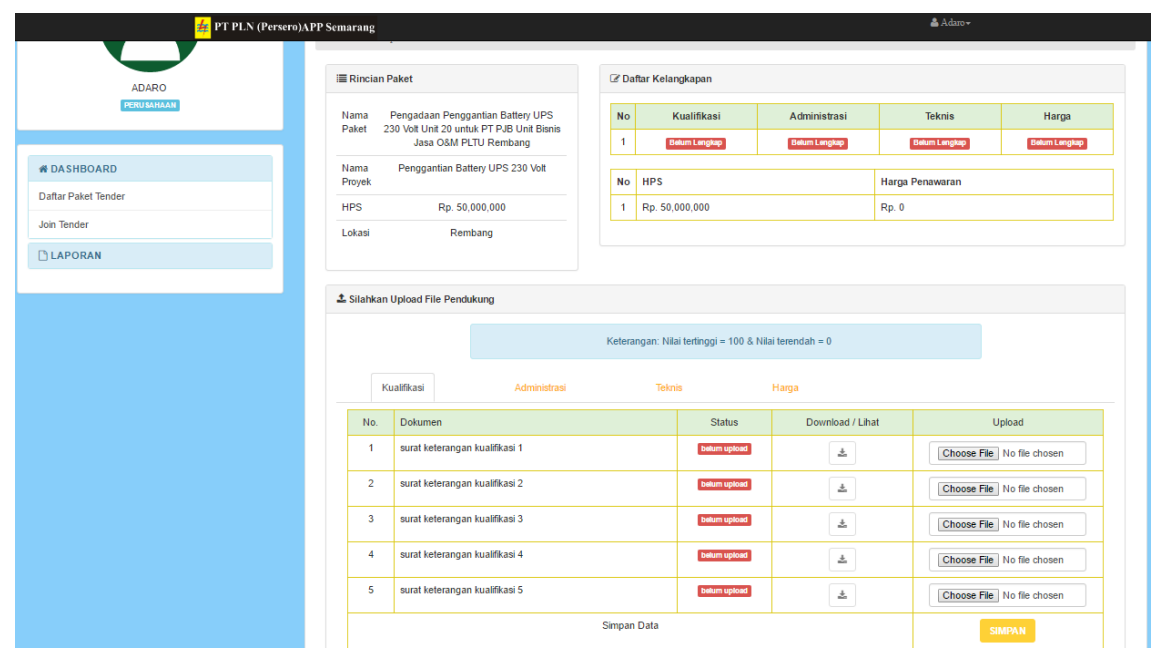

Figure 3. Input tender document 
After each of these sub-criteria entered, the system will check the documents. If the documents have been entered and saved, then the system will check the data and provide notification of data completeness.

\subsection{Input of Rate and calculation of BCR}

Input assessment carried out by the tender committee. Before performing the assessment input, the system will check the validation of the document. Validation by bidders is essential in this system because the committee was not able to evaluate the tender documents that have not been validated by prospective bidders. The committee can assess the qualification documents, administrative, and technical while the price assessment is done automatically by the system. Input weighting of votes in the form of the numbers one through five. In the qualifying criteria, administrative, and technical has five sub-criteria. If the number of the fifth sub-criteria value of less than 15 , the document did not pass. While the pricing criteria have one sub-criteria. If the value is less than three sub-criteria, the document did not pass. Figure 4 is an example of input assessment.

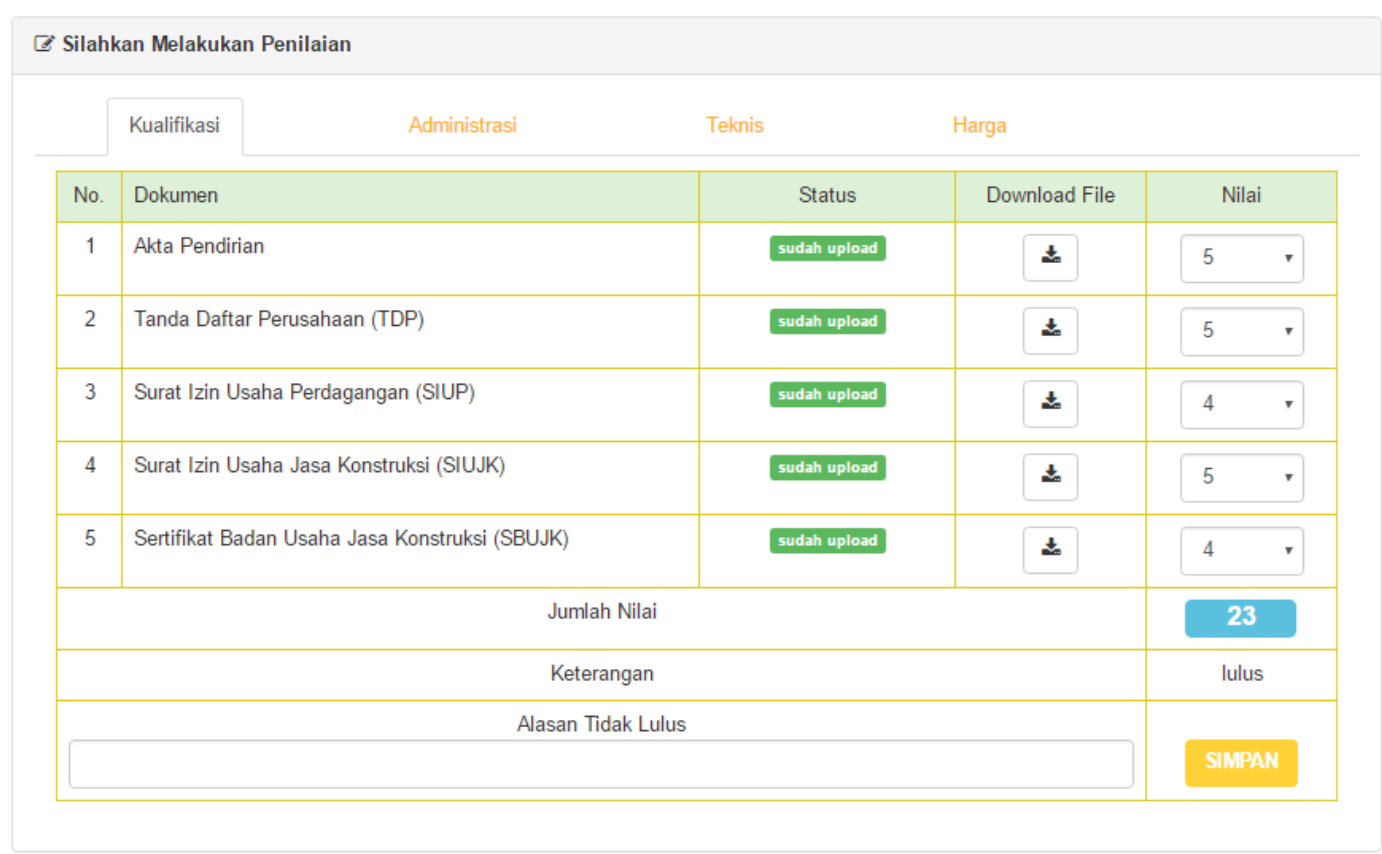

Figure 4. Input of rate

After the entire document has been rated by the tender committee, hereinafter that the calculation of BCR. The application of the calculation of BCR into present value, namely:

$$
\mathrm{BCR}=\frac{\text { PV Benefits }}{\text { PV Costs }}
$$

In this system is weighted with the following conditions:

$$
\begin{aligned}
& \text { Benefits }=\frac{\text { HPS X Total Weight }}{48} \\
& \text { BCR }=\frac{\text { Benefits }}{\text { HPS }}
\end{aligned}
$$

a. If the value of $\mathrm{BCR}<1$ then the benefits of the project is less than the cost required economically, the project is not feasible.

b. If the value of $\mathrm{BCR}=1$ then the benefits of the project together with the necessary economic costs, the project is feasible. 
c. If the value of $\mathrm{BCR}>1$ then the benefits of the project outweigh the costs necessary economically, the project is feasible.

Source code BCR calculation shown in Figure 5. After going through the assessment phase, the next step is to validate the winning bidder. The committee can decide the winner based on several aspects of the assessment project using the BCR at the offering price, benefits, and costs in accordance with requirements the company so that the project is feasible. Data winning bidder is shown in Figure 6.

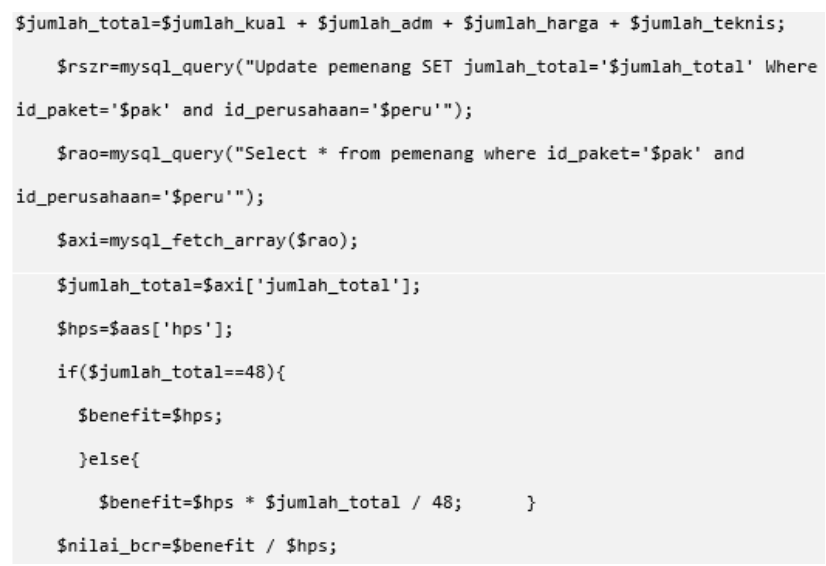

Figure 5. Source code BCR calculation

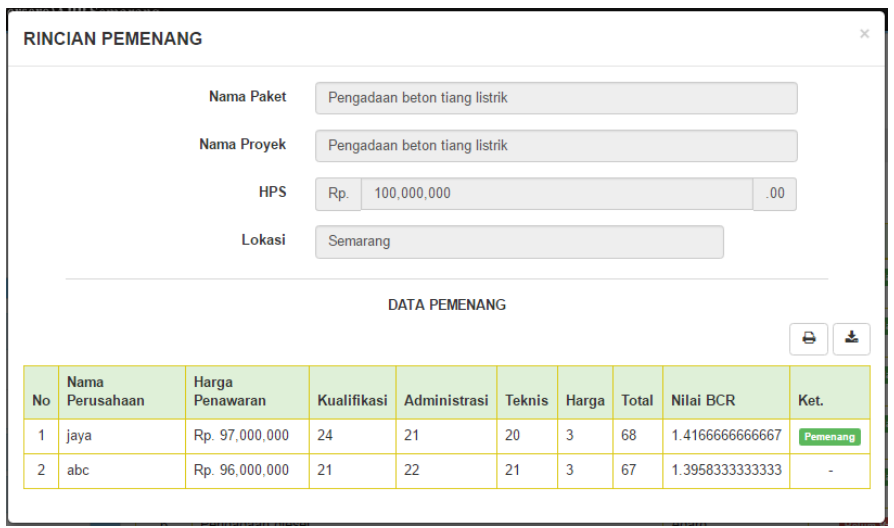

Figure 6. Data of tender winner

\section{Conclusion}

Ways of making the tender decision support system using Benefit Cost Ratio at. PLN (Persero) APP Semarang with PHP and MySQL the first step is to create a database system locally. The second step is to make authentication and authorization system. This system has three levels, namely the admin user, the committee and the company. Users who successfully login will get authorization so that each user has different permissions.

\section{References}

[1] Yakub. 2012. Pengantar Sistem Informasi. Graha Ilmu, Yogyakarta.

[2] Kusrini. 2007. Konsep dan Aplikasi Sistem Pendukung Keputusan. ANDI, Yogyakarta.

[3] Giatman, M. 2006. Ekonomi Teknik. PT. Raja Grafindo Persada, Jakarta.

[4] Arief, MR. 2011. Pemrograman Web Dinamis Menggunakan PHP dan MySQL. ANDI, Yogyakarta.

[5] Saputro, Haris dan Sugiri. 2008. Pengelolaan Database MySQL dengan PHPMyAdmin. Graha Ilmu, Yogjakarta.

[6] Pressman, RS. 2010. Software Engineering: a practitioner's approach. McGraw-Hill, New York. 